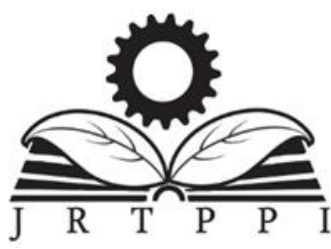

Vol. 12 No. 1 (2021) 39-54

Jurnal Riset

Teknologi Pencegahan Pencemaran Industri

Kementerian

Perindustrian

REPUBLIK INDONESIA

Journal homepage : http://www.jrtppi.id

\title{
Modelling Green Production Process in the Natural Dyes Batik Industry Using Cleaner Production Options
}

\author{
Siti Ajizah ${ }^{1}$, Nur Hidayat ${ }^{1}$, and Sri Suhartini ${ }^{1}$ \\ ${ }^{1}$ Brawijaya University, Malang, Indonesia
}

\begin{tabular}{l} 
A R T IC L E I N F O \\
\hline Article history: \\
Received 13 April 2021 \\
Received in revised form 18 May 2021 \\
Accepted 23 May 2021 \\
Available online 27 May 2021 \\
\hline Keywords : \\
Green production process \\
Cleaner production options \\
Natural dyes batik \\
Bayes method
\end{tabular}

\begin{abstract}
A B S T R A C T
Sustainable production policy has encouraged batik industry to switch synthetic dyes to natural dyes. However, the production process still brings negative impacts on the environment and humans. To solve this problem, the batik industry needs to develop green production process model using cleaner production options. The purpose of this research is to identify opportunities for implementing cleaner production, to select clean production options, and to present a green production process model of the natural dyes batik industry. The research was conducted in the natural dyes batik industry "Mbah Guru". Mbah Guru Industry is located in Lamongan, East Java. The research used Bayes method to assess and determine cleaner production options based on technical, economical, and environmental aspects. The last decision making of the options was used a feasibility study by using Pay Back Period (PBP). The Bayes method was used to make conclusions quickly. The results showed that Mbah Guru Industry produces waste per year as much as $72 \mathrm{~kg}$ of wax waste, $648 \mathrm{~kg}$ of ginger and natural dyes material waste, and $42.075 \mathrm{~m}^{3}$ of wastewater. The wastewater contains BOD of 343.71 $\mathrm{mg} / \mathrm{L}$, COD of $1352 \mathrm{mg} / \mathrm{L}$, TSS of $2828.57 \mathrm{mg} / \mathrm{L}$, oil and fat of $5.97 \mathrm{mg} / \mathrm{L}$, and $\mathrm{pH}$ of 3.65. The best option is "natural dyes wastewater reusing". it becomes the most priority of the options and has the best feasibility value with a payback period of 0.11 . The batik industry will be more profitable if it is able to implement the recommended process improvements so that the negative impacts, both on the environment and humans, can be minimized. The model would give a clear guidance to existing entrepreneurs and aspiring entrepreneurs on how to green the natural dyes batik industry.
\end{abstract}

\section{INTRODUCTION}

Batik is a patterned cloth with coloring by traditional techniques using wax (Syahputra \& Soesanti, 2016) that is globally known as Indonesian heritage. Batik has good potentials in economy and social. The Industrial Ministry of Republik Indonesia (2019) reported that batik export in the first semester of 2019 reached US \$ 17.99 million. Batik industry also has a role in empowering women's welfare because most of the workers are women (Al Rasyid \& Asri, 2017).

\footnotetext{
*Correspondence author.

E-mail : siti.ajizah.indonesia@gmail.com (Siti Ajizah)
}

Recently, the increased environmental awareness and pollution control have encouraged the use of natural dyes. They were considered non-allergenic, less toxic, noncarcinogenic, and more biodegradable than synthetic dyes (Maulik, Bhowmik, \& Agarwal, 2014). And also today mostly, batik craftsmen have realized the importance of this. However, natural dyes batik industry still gives negative impacts on the environment and humans. It uses water excessively and the wastewater contains total suspended solids (TSS), chemical oxygen demand (COD), biological 
oxygen demand (BOD), and color in high value, so has certainly contributed to pollution (Handayani, Kristijanto, \& Hunga, 2018a). It also still causes several diseases like respiratory disorders, skin diseases, kidney problems, low back pain (Hunga, 2014).

For the solution of this case, in Indonesia, sustainable policy production encouraged businesses to move to cleaner production (Handayani, Kristijanto, \& Hunga, 2018b). Nevertheless, there are several problems in batik SMEs for the application due to the lack of information on the characteristics and hazard levels of batik waste, the lack of information on appropriate technology for batik waste, and there is no information about waste management models that are easily understood by them.

Many researches have been carried out related to study and application of cleaner production in batik industry, including research conducted by Nurdalia (2006), Suhardi, Laksono, \& Fadhilah (2017), Hasibuan \& Hidayati (2018), Sirait (2018), Fauzi \& Defianisa (2019), and Riyanto, Subaderi, \& Nafi (2019). Nurdalia (2006) investigated at three stamped batik SMEs with synthetic dyes in Pekalongan (Clarasita, Fayza, Ismi). The research showed that each operating unit was inefficient, the saving measures taken were not significant, the waste discharge and pollution load were greater than the maximum threshold. The conducted research by Suhardi, Laksono, \& Fadhilah (2017) at Batik Puspa Kencana SME in Surakarta City (batik with synthetic dyes) found that cleaner production can be implemented by purchasing raw materials as needed and at the right time.
Hasibuan \& Hidayati (2018) researched in Batik Bogor (written batik, stamped batik, combination batik, and printing batik with synthetic and natural dyes). Cleaner production innovations that have been successfully applied are substitution of toxic dyes to non-toxic dyes, the use intensity of non-renewable energy reducing, solid waste reusing, and solid waste recycling. "Mosaic Batik" is one of the innovations of the solid waste batik utilization. Sirait (2018) ran the research at Batik Celaket SME in Malang (written batik industry with synthetic dyes). It resulted that the application of cleaner production can significantly reduce environmental impacts in terms of reducing COD of $89 \%$, BOD of $85 \%$, and TSS of $98 \%$.

Fauzi \& Defianisa (2019) researched at batik SMEs in Bogor, Batik Bumiku (natural dyes), and Batik Tradisiku (synthetic dyes). The quick scan results showed that the process of coloring, soaking, and rinsing are the main contributor to dyes waste. The use of natural dyes is considered the best strategy for realizing an environmentally friendly and sustainable batik industry, and the use of a bucket under the drying cloth to resist falling water is recommended as the best option. The conducted research by Riyanto, Subaderi, \& Nafi (2019) at written batik SMEs with synthetic dyes in Jetis Village, Sidoarjo (Namiroh, Dahlia, Azizah) found that the most feasible alternative technology applied to the Batik SMEs Sidoarjo is the application of appropriate technology for coloring process which can improve eco-efficiency in the production process of the batik-writing UKM in Jetis Village, Sidoarjo.

Table 1. Characteristics of Natural Dyes Batik Waste, Synthetic Dyes Batik Waste, and Quality Standards

\begin{tabular}{|c|c|c|c|c|c|}
\hline \multirow[b]{2}{*}{ Parameter } & \multicolumn{2}{|c|}{ Natural Dyes } & \multicolumn{2}{|c|}{ Synthetic Dyes } & \multirow{2}{*}{$\begin{array}{l}\text { Quality Standards } \\
\text { (Regulation of } \\
\text { Environmental } \\
\text { Ministry Number } 5 \\
\text { of 2014) }\end{array}$} \\
\hline & $\begin{array}{l}\text { Dyeing (Handayani, } \\
\text { Kristijanto, \& } \\
\text { Hunga, 2018a) }\end{array}$ & $\begin{array}{lr}\text { Wax Removal and } \\
\text { washing (Handayani, } \\
\text { Kristijanto, } \\
\text { Hunga, 2018a) }\end{array}$ & 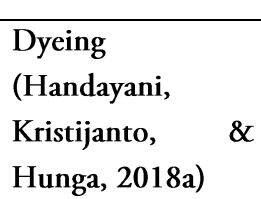 & $\begin{array}{l}\text { Wax Removal and } \\
\text { washing (Handayani, } \\
\text { Kristijanto, \& Hunga, } \\
\text { 2018a) }\end{array}$ & \\
\hline $\mathrm{pH}$ & 6.7 & 7.4 & 9.2 & 9.8 & $6.0-9.0$ \\
\hline TSS $(\mathrm{mg} / \mathrm{L})$ & 1470 & 16900 & 300 & 4200 & 50 \\
\hline Warna (PtCo) & 15270 & 51500 & 204500 & 43800 & - \\
\hline COD (mg/L) & 4000 & 16800 & 986.70 & 71200 & 150 \\
\hline $\mathrm{BOD}(\mathrm{mg} / \mathrm{L})$ & 209 & 380 & 185 & 237.82 & 60 \\
\hline
\end{tabular}


Based on all findings, until now there has been no research related to designing a model for implementing cleaner production in the batik industry in Indonesia, specifically in the natural batik industry. Therefore, it is very important to conduct a research related to designing a Green Production Model using cleaner production options in the natural dyes batik industry.

This paper aims to identify opportunities for implementing cleaner production, to select clean production options for better management of batik waste based on feasibility study using payback period and determination of priority using Bayes Method, as well as to present a green production process model of natural dyes batik industry based on cleaner production options. The model was developed after a field research that conducted at one of the popular batik heritage tourist destination in Lamongan, known as Mbah Guru batik industry. Mbah Guru batik industry is a Small-Medium Enterprise (SME) that has applied natural dying process.

In this work, an ideal model of batik production process was developed based on cleaner production options. The model would give clear guidance to existing entrepreneurs and aspiring entrepreneurs on how to green the natural dyes batik industry by actualizing cleaner production options upon the whole production process which is the novelty of this research. The formulated model would make the cleaner production becomes more practical, therefore it could ease the batik industrial players to understand and adopt the cleaner production options into their production process.

\section{METHOD}

\subsection{Subject of research}

The research was conducted at Mbah Guru batik industry, Jugo Village, Sekaran, Lamongan, East Java. Mbah Guru batik industry is a natural dyes batik smallmedium enterprise (SME) that was founded in 2016 and has become a tourist site for Lamongan culture advancement. It has marketed its batik fabric in the local and national markets and the production capacity is around $1500 \mathrm{~m} /$ year. For measurement of wastewater quality was carried out at Surabaya Standardization Research Center (Baristand of Surabaya).

\subsection{Data collection}

The data collection process was carried out using several methods. Identification of materials, energy, and waste used descriptive analysis (literature study, observation, survey, questionnaire, and interview), priority determination of options used Bayes Method, and strategy formulation used a feasibility study. The Bayes method was selected to determine the options priority because it can be used to make conclusions quickly on cases with multiple sources of measurement that cannot be handled by other methods such as complex hierarchical models.

\subsection{Stages of the Research}

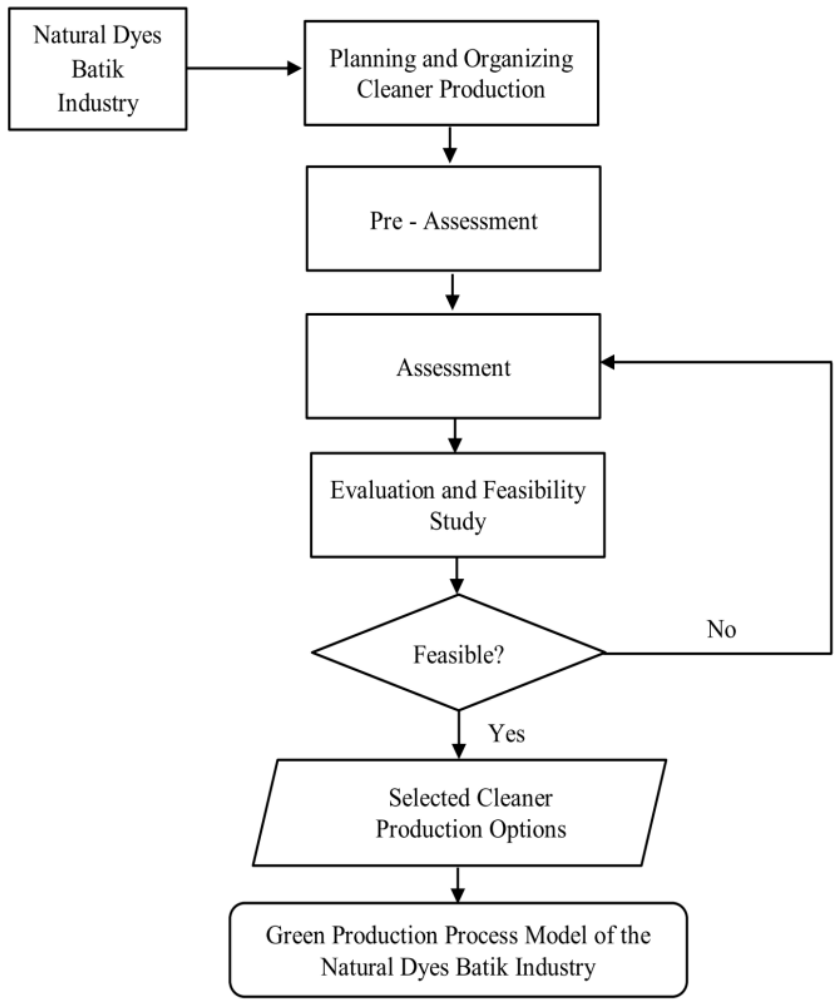

Figure 1. Flowchart of the research

\subsubsection{Planning and Organizing Cleaner Production}

At this stage, it focuses on obtaining the commitment of all members in the company, forming a competent team in the application of clean production, making environmental policies, setting goals and targets for implementing clean production, and preparing a study on 
the application of cleaner production (Gurbuz, Kiran-Ciliz, \& Yenigun, 2004).

\subsubsection{Pre-Assessment}

At this stage, information searches are carried out regarding company profile data and process flow diagrams, an inspection of the batik production process, emphasizing at which points of cleaner production aspects must be applied (Gurbuz et al., 2004).

\subsubsection{Assessment}

The most important thing in this step is the collection of data related to the amount of resources used, the products, the waste, and the emissions produced. By conducting the material balance assessment, it will be known the amount of input components used and the resulting output components, where the total input must be the same as the total output. The waste minimization could be attempted after observing the mass balance calculation (Gurbuz et al., 2004).

\subsubsection{Evaluation and Feasibility Study}

This step is an evaluation of the options in the previous stage to find out which options are feasible to be implemented from the priority list of options for implementing cleaner production (Gurbuz et al., 2004).

\subsubsection{Modelling Green Production Process}

After determining the selected cleaner production options in the stage of Evaluation and Feasibility Study, a green production process model was designed. This model integrated the production process and the selected cleaner production options and also integrated several elements related to the batik industry. The formulated model would make the batik industrial players easy to understand the description of cleaner production implementation.

\subsection{Data Analysis}

The data analysis consisted of priority scale analysis and feasibility study to assess and determine the selected cleaner production options.

\subsubsection{Priority Scale Analysis}

Expert systems are to learn how to adopt an expert in thinking and reasoning to make decisions and conclude a number of facts (Apriani, Perwira, \& Daulay, 2020). Bayes method is a method used to calculate the probability of an event (Perbawawati, Sugiharti, \& Muslim, 2019 and Susanti \& Manahan, 2020). Bayes probability is how to conquer data uncertainty (Sihotang, Riandari, Simanjorang, Simangunsong, \& Hasugian, 2019).

The study began with a questionnaire on the selection of cleaner production options. The questionnaire was given to experts in batik and environment. Here used three aspects consist of technical aspect, economical aspect, and environmental aspect. The expert respondents filled out the questionnaire using a Likert scale from 1 to 5 . The numbers show the low impact to high impact of criterion. Furthermore, the data was processed using Bayes method. According to Wardani, Aulady, Frido, \& Hendri (2021), the calculation of the score in Bayes method for each criterion is:

$$
\text { The total value } \mathrm{I}=\sum_{\mathrm{i}=1}^{\mathrm{m}} \mathrm{ij}(\text { Criteria }[\mathrm{ij}])
$$

Note:

The total value of $\mathrm{i}=$ The total value of the final value of the i- option

The value of $\mathrm{ij} \quad=$ The value of the $\mathrm{i}$ - option in the $\mathrm{j}$ criteria

Critical j

$=$ Level of importance (weight) the $\mathbf{j}$ criterion

$\mathrm{i}=1,2,3, . . \mathrm{n} ; \quad \mathrm{n} \quad=$ Number of options

$\mathrm{j}=1,2,3, . . \mathrm{m} ; \quad \mathrm{m}=$ Number of criteria

Calculations to find the weight value per criterion, total weight, and probability value per criterion can be done in the following ways (Sibagariang \& Riandari, 2019):

a. Weight Per Criterion is calculated by adding up the value of the options on each question for each criterion.

b. Total weight is calculated by adding up all of the weight values for each criterion. 
c. Probability Per Criterion is calculated by calculating the weight per criterion divided by the total weight.

d. Total Probability, obtained by adding the overall probability value of each criterion with the total must be 1.

\subsubsection{Feasibility Study of the Proposed Cleaner Production} Options

Cleaner production options can save some money on the costs involved in production process and provide a new revenue source. Many Cleaner production options have a little cost, and can be very lucrative but others must be carefully analyzed to weigh their profitability. Economic feasibility analysis is carried out to determine whether cleaner production options are feasible or not. If the selected cleaner production options need costs for equipment installation or operation, a feasibility study is needed. Payback period is a quick method for comparing the options (Anonymous, 2005).

According to Anonymous (2005), the pay back period measures the ability to return on investment in terms of time. According to Anonymous (2016), the pay back period formula is:

Pay back period formula when the cash flow per year is the same

Pay back period (in years) $=\frac{\text { Initial investment Cost }}{\text { Annual Operating Savings }}$

Pay back period formula when the cash flow per year is different.

Pay back period $=n+\frac{(a-b)}{(c-b)} \times 1$ year

Note:

$\mathrm{n}=$ The last year the amount of cash flow has not been able to cover the initial investment cost

a $\quad=$ The initial investment amount

$\mathrm{b}=$ The cumulative amount of cash flows in year $\mathrm{n}$

$\mathrm{c} \quad=$ The cumulative amount of cash flows in year $(\mathrm{n}$ $+1)$
If an investment option has a faster payback period than the economic life, the option is feasible. If an investment option has a longer payback period than the economic life, the option is not feasible. If there are more than one proposed investment options, the earlier payback period will be selected.

\section{RESULTS AND DISCUSSION}

\subsection{Planning and Organizing Cleaner Production}

Mbah Guru Batik Industry has a policy to take actions that lead to the creation of an environmentally friendly industry, one of which is by switching from synthetic dyes to natural dyes, utilizing the extraction wastewater to water dyes plants, providing gardens so as not to buy dyes from outside so that it can save energy and avoid damaging the material due to excess supply caused it has expired, the use of sack waste for safety from wax droplets when chanting process, providing infiltration wells for waste treatment, and utilization of extraction dregs for making compost but composting is done only by adding rice washing wastewater to the dregs.

According to Sirait (2018), material input substitution by switching chemical dyes to natural dyes indicated that significantly improved the environmental performance by reducing BOD of $85 \%$, COD of $89 \%$, and TSS of $98 \%$. The application of cleaner production is intended to increase productivity, reduce costs, and can become a pilot batik industry, especially in waste management. The target of implementing cleaner production is directed at materials, water, energy, occupational health and safety, waste, and pollution.

\subsection{Pre-Assessment}

\subsubsection{Natural Dyes Batik Making Process}

Before batik making process, we should make mordant solution and natural dyes solution first. For mordant solution preparation, here using alum, soda ash, chopped ginger, and water. Chopped ginger is covered using a small piece of cloth so that its dregs do not contaminate the solution. Furthermore, alum, soda ash, chopped ginger, and water are boiled together. For natural dyes solution 
preparation, here used natural dyes material which is cut and mashed. After that, it is extracted by cooking it in table salt solution. Let it cool and filter it using sieve.

In the initial step of natural dyes batik making process is the fabric providing by soaking it in Turkish Red Oil (TRO) solution or concentrate detergent solution to remove starch that effects the quality of coloring. After that, the fabric is washed and let it dry naturally in air drying.
Then continued drawing pattern using pencil. Drawing pattern can be directly or by copying the pattern behind the fabric. After it, followed by pattern framing, pattern frame filling, pattern frame copying on the back surface, and the certain parts covering processes by applying hot wax using canting. After applying wax, the fabric is washed by soaking in TRO solution, washed using water, and dried using air drying.

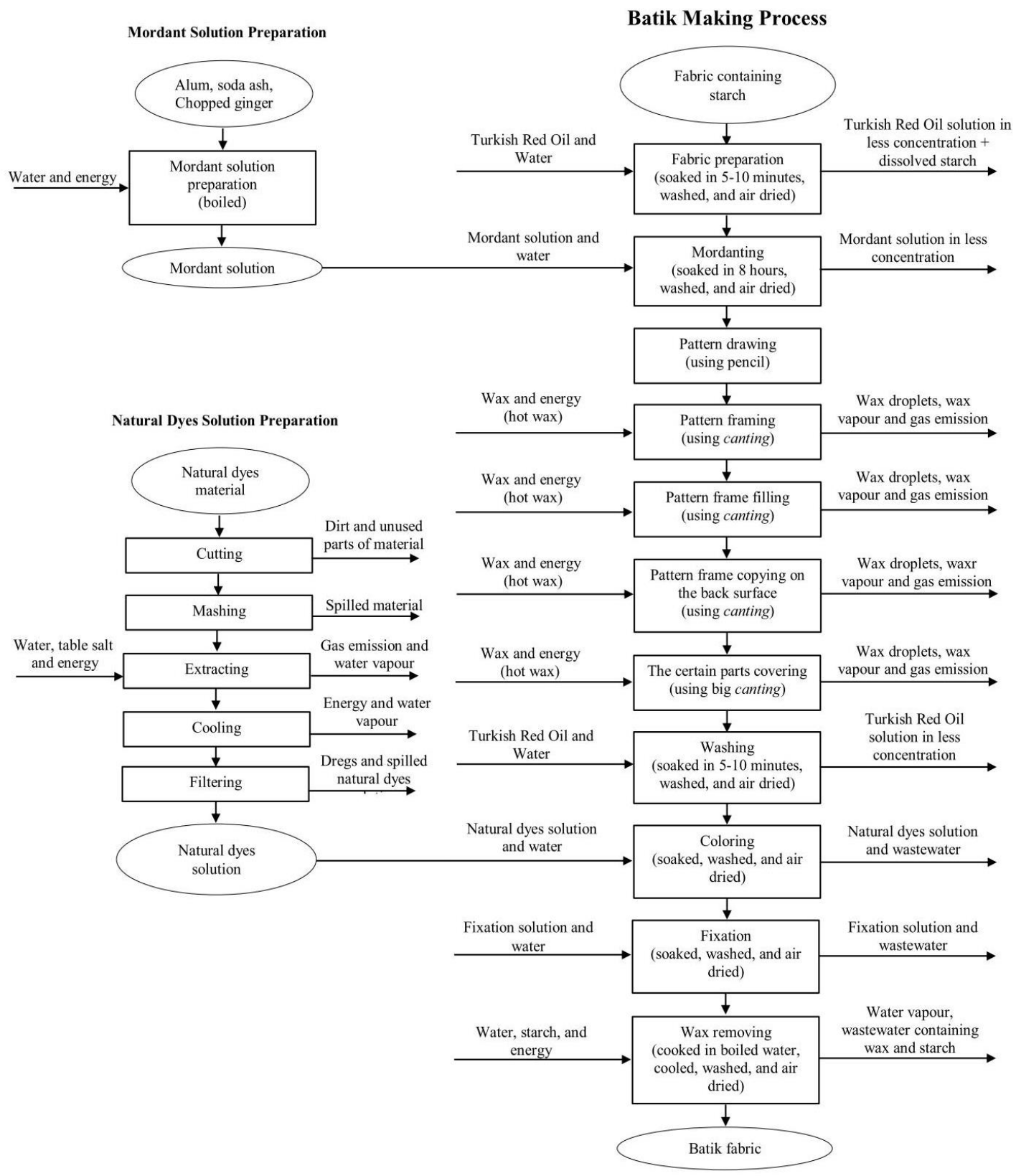

Figure 2. Flowchart of Batik Making Process 
Table 2. The Requirement Structure of Material, Water and Energy Per Meter of Output with the Benchmark Data Structure

\begin{tabular}{ccccc}
\hline No. & Materials Requirement & Unit & Benchmark Data (Nurdalia, 2006) & Mbah Guru \\
\hline 1 & Dyes & gram & $\left.0.5-6^{* *}\right)$ & 3.52 \\
2 & Wax & gram & $\left.100-150^{*}\right)$ & 100 \\
3 & Water & liter & $25-50$ & 33 \\
4 & Electricity & $\mathrm{kWh}$ & $5-15$ & 178 \\
5 & Kerosene & $\mathrm{ml}$ & $25-50$ & 150 \\
6 & Firewood & gram & $100-150$ & 450 \\
\hline
\end{tabular}

*) depending on the motive

${ }^{* *}$ ) the requirement per color

Table 3. Comparation of Quality Mbah Guru Wastewater and Quality Standards

\begin{tabular}{|c|c|c|c|}
\hline \multirow[b]{2}{*}{ Parameter } & \multirow{2}{*}{$\begin{array}{l}\text { Wastewater Quality of Mbah } \\
\text { Guru *) }\end{array}$} & \multicolumn{2}{|l|}{ Quality Standards } \\
\hline & & $\begin{array}{l}\text { Regulation of Environmental } \\
\text { Ministry Number } 5 \text { of } 2014\end{array}$ & $\begin{array}{l}\text { East Java governor Regulation No. } \\
72 \text { of } 2013\end{array}$ \\
\hline $\mathrm{COD}(\mathrm{mg} / \mathrm{l})$ & 1352 & 150 & 150 \\
\hline TSS $(\mathrm{mg} / \mathrm{L})$ & 2828.57 & 50 & 50 \\
\hline $\mathrm{pH}$ & 3.65 & $6.0-9.0$ & - \\
\hline
\end{tabular}

$\left.{ }^{*}\right)$ test results in Baristand of Surabaya

Furthermore continued by coloring, fixation, and wax removing processes. In coloring process, the fabric is soaked in natural dyes solution, washed using water, and air dried. In fixation process, the fabric is soaked in the fixation solution, washed using water, and air dried. In wax removal, add starch to water and boiled. Enter the fabric into the water. After all the wax is removed, take the fabric and cool it. And then it is washed using water and dried using air drying.

\subsubsection{Input Requirement and Produced Output}

From $1500 \mathrm{~m}$ of batik cloth produced, approximately are needed $52.78 \mathrm{~kg}$ of natural dyes, $150 \mathrm{~kg}$ of wax, $49.5 \mathrm{~m}^{3}$ of water, $266.27 \mathrm{kWh}$ of electricity, 225 liters of kerosene, $168.75 \mathrm{~kg}$ of firewood, and $120 \mathrm{~kg}$ of gas. Kerosene is used for chanting process, firewood is used for wax removing process and gas is used for mordant solution preparation, extraction, and sometimes for wax removing. If the price of gas is converted to the price of firewood, it is equivalent to about $506.25 \mathrm{~kg}$ of firewood. Firewood is selected as comparation because the price is cheaper than kerosene. To find out whether the requirement structure of material, water, and energy per meter of product is efficient or not, it is necessary to compare it with the benchmark data structure as in Nurdalia (2006) as follows.

Based on Table 2, can be seen that the use of electricity, kerosene, and firewood is above the benchmark. This indicates that there are inefficiencies in the use of electricity, kerosene, and firewood. The waste of electricity use because the volume of production is still below production capacity. The waste of kerosene occurs because of the waiting time and the insufficient amount of the cloth in one chanting process. Likewise with firewood, there is waste due to the waiting time and the amount of the cloth is still below the capacity in every wax removing process. The use of dyes and water is actually quite efficient, but efforts can still be made to increase efficiency.

Mbah Guru Batik Industry produces $72 \mathrm{~kg}$ of wax waste per year, $648 \mathrm{~kg}$ of ginger and natural dyes material waste per year, and $42,075 \mathrm{~m}^{3}$ of wastewater per year. The resulted wastewater is $85 \%$ of the water requirement as according to Indrayani (2018). So far, the wax waste is partially reused, the extraction dregs for making compost, and the wastewater is disposed of into 
infiltration wells. The main problem of environment in the batik industry is the wastewater in high pollutant levels (Dasgupta, Sikder, Chakraborty, Curcio, \& Drioli, 2015). To determine wastewater quality, a laboratory wastewater assessment was carried out and the results as in Table 3.

Based on Table 3, it can be seen that the quality of the wastewater produced in Mbah Guru for all parameters still does not meet the quality standards so that it needs treatment. The high concentrations of BOD, COD, and TSS in wastewater are caused by the high content of organic materials and chemicals. The characteristics of the wastewater occur because the raw materials used are organic materials. The organic material is broken down by microorganisms so that the BOD and COD concentrations of wastewater are high (Sirait, 2018). Both pollution and water inefficiency cause water scarcity. Efforts are needed to prevent scarcity (Handayani, Kristijanto, \& Hunga, 2018a).

Table 4. Proposed Cleaner Production Options

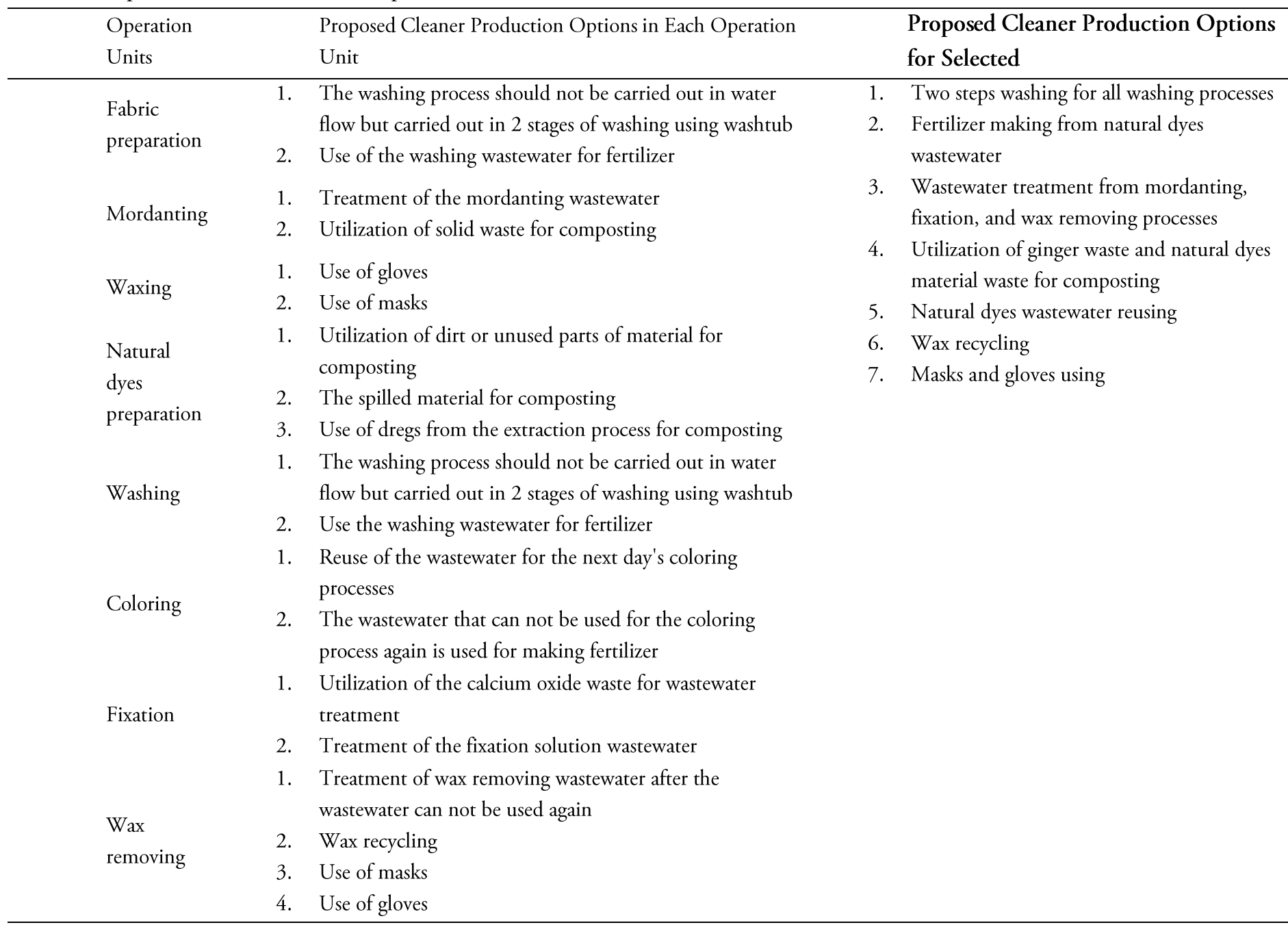

Table 5. Criteria Weighting by Experts

\begin{tabular}{|c|c|c|c|c|c|c|}
\hline \multirow{2}{*}{ No. } & \multirow{2}{*}{ Criteria } & \multicolumn{3}{|c|}{ Score } & \multirow{2}{*}{ Total } & \multirow{2}{*}{ Bayes Weight } \\
\hline & & R1 & $\mathrm{R} 2$ & R3 & & \\
\hline 1 & Technical Aspect & 2 & 3 & 3 & 8 & $8 / 34=0.24$ \\
\hline 2 & Economical Aspect & 5 & 3 & 4 & 12 & $12 / 34=0.35$ \\
\hline 3 & Environmental Aspect & 5 & 4 & 5 & 14 & $14 / 34=0.41$ \\
\hline \multicolumn{2}{|c|}{ Total weight } & & & & 34 & 1 \\
\hline
\end{tabular}




\subsubsection{Identification of Cleaner Production Options}

The cleaner production implementation contributes significantly in improving the performance of environment during the batik production (Sirait, 2018). The production process was observed to discover where cleaner production opportunities can be run. The production process consists of several operation units. A walking-through process was carried out at each operation unit to analyze what cleaner production options can be proposed. After making several suggestions for cleaner production options, they were summarized for analysis. The proposed cleaner production options can be seen in Table 4.

There are several processes that should be carried out on a large scale to save on the use of water, kerosene, dyes, fixation solutions, or firewood which will provide benefits if done. However, this option cannot be proposed because the company is still producing according to order and the orders are still limited, so the number of batik produced per day cannot be determined. In order to save the electricity usage, the production volume should be increased. However, this cannot be done because it has to adjust to market demand. Therefore, this option was not proposed. Initially, the use of wax waste was only partial. In this option, it is proposed to recycle all wax waste and reuse it for the purposes of the production process. Initially, the extraction liquid waste was only used for watering the plants, here it is proposed to make liquid fertilizer.

Extraction dregs are used for composting. From the proposed options, not only extraction dregs which are used for composting but also ginger waste from the mordanting process and waste of unused dyes material from the cutting process and spilled dyes material from the mashing process. In addition, the compost that was made not only used rice washing water but also added bioactivators. This is because the rice washing water only lasts for one day and after that, it will stale and the microbes in it will die so it is necessary to add a bioactivator as a decomposer material.

For the waste that enters the infiltration wells, the option proposes decrease in volume by proposing "twostage washing" option which can reduce the volume of washing wastewater by almost $50 \%$. In addition, activated charcoal is added as an ingredient for wastewater treatment where initially it only uses palm fiber, sand, gravel, and bricks. Activated carbon is very important to add, especially to absorb chemicals used during the batik-making process.

\subsection{Selection of Cleaner Production Options}

The implementation of cleaner production is based on three aspects, namely technology, policy, and finance (payback period) (A. M. Fauzi, Rahmawakhida, \& Hidetoshi, 2008). Policy priorities or option priorities were analyzed using the Bayes method.

\subsubsection{Priority Determination Using Bayes Method}

After determining what the cleaner production options would be analyzed, we determined the priority scale of them using Bayes Method to sort out which the cleaner production options should take precedence.

\subsubsection{Criteria Weighting}

Based on information obtained from several literatures, 3 criteria for selecting cleaner production options were used. They are technical aspect, economic aspect, and environmental aspect. The technical aspect relates to the time of production process is not too long, the high resulted yield, the convenience of the option implementation, either in terms of equipment procurement or operation. The economic aspect relates to the significance of added value provided by the option and considers the costs required and the benefits obtained. The environmental aspect relates to the given effect significance of the option implementation to the environment based on reducing waste and improving environmental performance. The weighting criteria were carried out by experts which would be the basic in determining the Bayes weight.

In Table 5 can be seen that the highest criterion weight is the environmental aspect of 0.41 and followed by the economical aspect of 0.35 . This shows that the environmental aspect and economical aspect are priorities taken into consideration in selecting cleaner production options. As in study of Ulya \& Hidayat (2018), these criteria are expected to have an effect on reducing the generation of waste both solid waste and liquid waste 
around the industry without neglecting the production costs that will become a burden to the industry. In contrast to the research results of Suhardi, Laksono, \& Fadhilah (2017) where after environmental criteria, technical criteria are the priority for consideration. This is due to the different characteristics of the proposed options where they do not really need economic considerations because they do not require costs or are very affordable.

Table 6. Options Weighting to the Criteria

\section{Criteria}

\section{No. Cleaner Production Options}

$\begin{array}{lc}\text { Option } & \text { Priority } \\ \text { Weight } & \text { Scale }\end{array}$

\begin{tabular}{|c|c|c|c|c|c|c|}
\hline 1 & $\begin{array}{l}\text { Two steps washing for all washing } \\
\text { processes }\end{array}$ & 4.3 & 4 & 4.3 & 4.195 & 3 \\
\hline 2 & $\begin{array}{l}\text { Fertilizer making from natural dyes } \\
\text { wastewater }\end{array}$ & 4 & 4.3 & 4.7 & 4.392 & 2 \\
\hline 3 & $\begin{array}{l}\text { Wastewater treatment from } \\
\text { mordanting, fixation, and wax } \\
\text { removing processes }\end{array}$ & 3 & 3.3 & 4 & 3.515 & 6 \\
\hline 4 & $\begin{array}{l}\text { Utilization of ginger waste and } \\
\text { natural dyes material waste for } \\
\text { composting }\end{array}$ & 4 & 3.7 & 4.3 & 4.018 & 5 \\
\hline 5 & Natural dyes wastewater reusing & 4.7 & 5 & 5 & 4.928 & 1 \\
\hline 6 & Wax recycling & 3 & 4.3 & 4.7 & 4.152 & 4 \\
\hline 7 & Masks and gloves using & 3.7 & 3.3 & 2.3 & 2.986 & 7 \\
\hline & Bayes Weight & 0.24 & 0.35 & 0.41 & & \\
\hline
\end{tabular}

Table 7. Economic Feasibility Analysis of the Cleaner Production Options

\begin{tabular}{|c|c|c|c|c|c|}
\hline No. & Cleaner Production Options & Investment Cost & $\begin{array}{l}\text { Annual Operating } \\
\text { Saving }\end{array}$ & Payback Period & Feasibility \\
\hline 1 & $\begin{array}{l}\text { Two steps washing for all washing } \\
\text { processes }\end{array}$ & 60,000 rupiahs & 65,160 rupiahs & 0.92 years & Feasible \\
\hline 2 & $\begin{array}{l}\text { Fertilizer making from natural dyes } \\
\text { wastewater }\end{array}$ & 224,000 rupiahs & $3,940,000$ rupiahs & 0.057 years & Feasible \\
\hline 4 & $\begin{array}{l}\text { Utilization of ginger waste and natural } \\
\text { dyes material waste for composting }\end{array}$ & 150,000 rupiahs & 624,000 rupiahs & 0.24 years & Feasible \\
\hline 5 & Natural dyes wastewater reusing & $1,300,000$ rupiahs & $11,591,017.5$ rupiahs & 0.11 years & Feasible \\
\hline 7 & Masks and gloves using & 120,000 rupiahs & 70,000 rupiahs & 0.58 years & Feasible \\
\hline
\end{tabular}




\subsubsection{Options Weighting to the Criteria}

The next step is options weighting to the criteria. Results of the each options weighting to several criteria were determined by the experts and can be seen in Table 6 .

From the data in Table 6 we can see that the most priority of the cleaner production options is "natural dyes wastewater reusing" and followed by "fertilizer making from natural dyes wastewater", "two steps washing for all washing processes", "wax recycling", "utilization of ginger waste and natural dyes material waste for composting", "wastewater treatment from mordanting, fixation, and wax removing processes", and "masks and gloves using". "Natural dyes wastewater reusing" is the most important to be implemented, reviewed based on technical, economic, and environmental criteria. Based on technical criteria, it is very easy to implement because it has no process before reusing process. Based on economic and environmental criteria, this option become the best option because a large initial cost is only for providing refrigerator, the operating costs are very little, and it provides significant economic and environmental benefits. By reusing dyes waste as a coloring agent can reduce the cost of procuring dyes and indirectly reduce the negative impact on the environment because the amount of waste generated can be reduced. Production operators have to really maximalize in using dyes before 3 days so that they can save more on the use of dyes and can also reduce dyes that become waste.

On the other hand, "masks and gloves using" is the least priority. Based on technical criteria, "masks and gloves using" is clear that it is very easy to do because it is just a matter of procuring or purchasing masks and gloves. However, from an economic point of view, it requires routine costs with the same expenditure in each period, while the benefits that are obtained are only benefits related to worker health and safety, namely improving the health of workers because workers are protected from inhaling gas pollution and also protecting their hands from being exposed to chemicals during processes that use chemicals and hot steam during the processes of boiling water or hot wax when chanting processes.

\subsection{Feasibility Study}

After we knew whether the cleaner production options are feasible or not, we conducted Economic Feasibility Analysis on them. If they are feasible, the cleaner production options would be selected to be implemented or for making green production process model.

Based on Table 7 we can see that the payback period of each option is under one year and all of the cleaner production options are feasible. It means that they can be implemented in this industry. "Fertilizer making from natural dyes" has the shortest payback period with significant profit but requires total of the operational cost more than twice of total of the profit. "Two steps washing for all washing processes" has the longest payback period, almost one year but does not require operational cost at all and the equipment procurement costs are quite little (only 60,000 rupiahs) even though the annual profit is the same (65,160 rupiahs). "Natural dyes wastewater reusing" has the second shortest payback period with a large equipment procurement cost, but the benefit is very significant.

The feasible options that have a high priority are is a priority to implement because according to Sirait (2018), they would be effective for improving environmental performance. In this research, the option of "Natural dyes wastewater reusing" becomes the best option to implement because besides having the highest priority, it also has the best feasibility value with a payback period value of 0,11 . Another reason that the option is easy to do because it can be done even though there is a limited time or a lack of knowledge of either the owner or the workers.

\subsection{Green Production Process Model}

The last step is green production process model making. According to Yaacob \& Zain (2016), a green batik industry model resulted from green options is proposed to give benefit to the planet, profits and people. Because all of the cleaner production options are feasible, so they are all selected for making green production process model. In modeling, to avoid a confusion, different line colors were used for each option. The model of green batik production process can be seen in Figure 3 . 


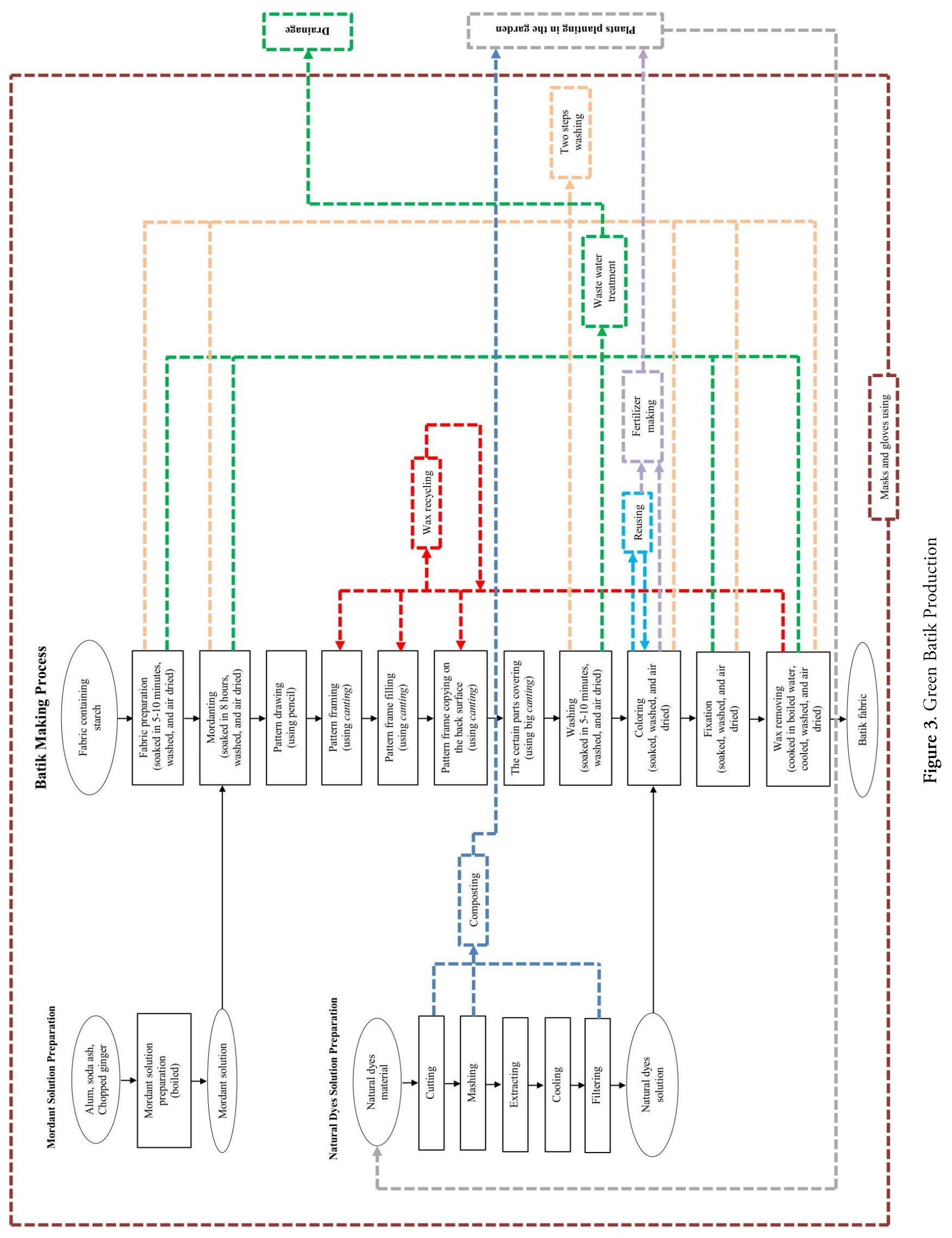


The produced solid waste in the preparation of the natural dye, from the cutting, mashing, and filtering processes goes into the composting process where the produced compost will be used for planting dye plants in the garden. All of the washing processes in the fabric preparation, mordanting, washing, coloring, fixation, and wax removing processes use "two steps washing". The wastewater from the fabric preparation, mordanting, washing, fixation, and wax removing processes goes into "wastewater treatment" process where the treated water will be discharged to drainage.

The natural dyes solution (after used) from the coloring process is stored to go into the reusing process in the next day. However, after the natural dyes solution can no longer be used, it and the wastewater from washing in coloring process will enter the fertilizer making process and the produced fertilizer will be used to fertilize the natural dye plants in the garden. All waste waxes from the waxing processes and from the wax removing process goes into the wax recycling process. The recycled wax is reused for the waxing process. During the production process, all workers are required to wear masks and gloves for occupational health and safety.

Mbah Guru Batik Industry has a large area for planting natural dye plants. The various types of plants are planted there. Mbah Guru Batik Industry also has a waste treatment facility, in the form of infiltration wells. The taken action plan on the waste is adjusted to the availability of the owned facilities. It is the reason why the produced fertilizers are not sold but used for internal purposes and the wastewater treatment uses infiltration wells.

In contrast to the results of research by Malaysian Department of Environment (2013) in Yaacob \& Zain (2016) where model was built from options consisting of good ventilation, reusable wax produced for patterning batik, sell off excess wax, prepare a sealed dye container and labeled, soaking the fabric in bulk, recycling of surplus raw materials, provide proper drainage system to be channeled directly into the treatment system, and provide an appropriate water treatment system. This is because the conditions that occur in each company, the types of dyes used, and the policies in each company are different.

At Mbah Guru batik industry, there is no need to improve ventilation because the production site is designed to be open, no sales of wax are carried out because it is not excessive, it is not recommended to provide tightly closed containers and labeling because of no dyes stocking. The storage of dyes is carried out for dyes that have been used which will be reused the next day and the storage and labeling processes have been carried out properly. There is also no option for providing a wastewater treatment system because it is already available and no option to connect between the drainage system and the wastewater treatment system because they have been well connected. Raw material surplus is related to company policy in raw material procurement. Here it is not proposed to recycle the surplus raw materials because the material procurement arrangements are well organized. it also does not recommend the soaking in bulk because the orders are still limited.

In the research of the Malaysian Department of Environment (2013) in Yaacob \& Zain (2016), it is not recommended to reuse dyes wastewater, make compost, make liquid fertilizer because the dyes used are synthetic dyes. It is also not recommended to use masks and gloves because safety and health protection to the workers have been carried out properly.

\section{CONCLUSION}

Based on the results, the best cleaner production option is "natural dyes wastewater reusing". It has the highest priority and the best feasibility value with a payback period of 0.11 . The results of this study could be explicitly implemented to Mbah Guru Batik Industry and other similar industries by using several adjustment variables for financial calculations. The Lamongan Regency Government can provide funding to help Mbah Guru Batik Industry initiate the implementation of cleaner production options to become a pilot batik industry for other batik industries. 
Among the cleaner production options identified for upgrading Mbah Guru Batik industry to a green batik industry such as "natural dyes wastewater reusing", "fertilizer making from natural dyes wastewater", "two steps washing for all washing processes", "wax recycling", "utilization of ginger waste and natural dyes material waste for composting", "wastewater treatment from mordanting, fixation, and wax removing processes", and "masks and gloves using" which should be applied in the industry for greening the batik industry to prevent the negative impacts on humans and the environment. The model would give a clear guidance to existing entrepreneurs and aspiring entrepreneurs on how to green the natural dyes batik industry using cleaner production options upon the whole production process. For the future research can be made a research related to modelling in natural dyes batik industry but without having empty land for gardening and infiltration wells for water treatment so that can give different analysis.

\section{ACKNOWLEDGMENT}

The authors would like to thank Mbah Guru Batik Industry for giving the opportunity to conduct this research. Thanks also to the supervisors for the guidance and to all respondents who helped collecting the data.

\section{REFERENCE}

Al Rasyid, M. R., \& Asri, R. W. P. (2017). Waste Prevention Effectiveness of Batik Production in Yogyakarta, Indonesia. ICoSI 2014, 473-481. https://doi.org/10.1007/978-981-287-661-4_46

Anonymous. (2005). Cost Analysis for Pollution Prevention. Hazardous Waste and Toxics Reduction Program, Department of Ecology, Washington State.

Anonymous. (2016). Engineering Economics. Sam Ratulangi Manado University.

Apriani, W., Perwira, Y., \& Daulay, S. (2020). Expert System of Pest Diagnosis in Passion Fruit Plants using the Bayes Theorem Method. International Journal of Innovative Technology and Exploring
Engineering, 9(4), 503-508. https://doi.org/10.35940/ijitee.d1312.029420

Dasgupta, J., Sikder, J., Chakraborty, S., Curcio, S., \& Drioli, E. (2015). Remediation of Textile Effluents by Membrane Based Treatment Techniques: A State of the Art Review. Journal of Environmental Management, 147, $55-72$. https://doi.org/10.1016/j.jenvman.2014.08.008

East Java governor Regulation No. 72 of 2013 about Wastewater Quality Standards.

Fauzi, A., \& Defianisa, R. (2019). Analysis for cleaner production implementation strategy in batik industry in Bogor Analysis for cleaner production implementation strategy in batik industry in Bogor. IOP Conf. Series: Earth and Environmental Science, 325:

01200.

https://doi.org/10.1088/17551315/325/1/012005

Fauzi, A. M., Rahmawakhida, A., \& Hidetoshi, Y. (2008). Study on Cleaner Production Strategy in The Small Scale Tapioca Industry: A Case Study in Kelurahan Ciluar, North Bogor Sub-District. Jurnal Teknologi Industri Pertanian, 18(2), 60-65.

Gurbuz, S., Kiran-Ciliz, N., \& Yenigun, O. (2004). Cleaner production implementation through process modifications for selected SMEs in Turkish olive oil production. Journal of Cleaner Production, 12(6), 613-621. https://doi.org/10.1016/S09596526(03)00121-5

Handayani, W., Kristijanto, A., \& Hunga, A. (2018). A water footprint case study in Jarum village, Klaten, Indonesia: The production of natural-colored batik. Environment, Development and Sustainability, 21(4), 1919-1932. https://doi.org/10.1007/s10668-018-0111-5

Handayani, W., Kristijanto, A., \& Hunga, A. (2018). Behind the eco-friendliness of " batik warna alam . Wacana, 19(1), 235-256. https://doi.org/10.17510/wacana.v19i1.673.Dow nloaded 
Hasibuan, S., \& Hidayati, J. (2018). The Integration of Cleaner Production Innovation and Creativity for Supply Chain Sustainability of Bogor Batik SMEs. International Scholarly and Scientific Research \& Innovation, 12(5), 679-684. Retrieved from scholar.waset.org/1307-6892/10009386

Hunga, A. I. R. (2014). Threat of Ecological Destruction in Home-Based Batik Production: a Narrative of Protecting Domestic Sphere. Jurnal Perempuan: Untuk Pencerahan Dan Kesetaraan, 19(1).

Indrayani, L. (2018). Batik Industry Wastewater Processing As One Pilot IPAL Batik in Yogyakarta. ECOTROPHIC, 12(2), 173-184.

Maulik, S. R., Bhowmik, L., \& Agarwal, K. (2014). Batik on handloom cotton fabric with natural dye. Indian Journal of Traditional Knowledge, 13(4), 788794.

Nurdalia, I. (2006). Study and Analysis of Cleaner Production Opportunities in Stamped Batik Small Entreprise. Universitas Diponegoro.

Perbawawati, A. A., Sugiharti, E., \& Muslim, M. A. (2019). Bayes Theorem and Forward Chaining Method On Expert System for Determine Hypercholesterolemia Drugs. Scientific Journal of Informatics, $\quad 6(1), \quad$ 116-124. https://doi.org/10.15294/sji.v6i1.14149

Regulation of Environmental Ministry Number 5 of 2014 about Wastewater Quality Standards

Riyanto, O. A. W., Subaderi, \& Nafi, A. S. (2019). Penerapan Produksi Ramah Lingkungan Pada Proses Produksi UKM Batik Tulis. Prosiding PKM-CSR, 2.

Sibagariang, R., \& Riandari, F. (2019). Decision Support System for Determining the Best Wood For the Production Cabinet in PT.Tanjung Timberindo Using Bayes Method. Jurnal Mantik, 3(3), 99103. Retrieved from https://iocscience.org/ejournal/index.php/mantik/i ndex

Sihotang, H. T., Riandari, F., Simanjorang, R. M., Simangunsong, A., \& Hasugian, P. S. (2019).
Expert System for Diagnosis Chicken Disease using Bayes Theorem. Journal of Physics: Conference Series, 1230(1). https://doi.org/10.1088/17426596/1230/1/012066

Sirait, M. (2018). Cleaner production options for reducing industrial waste: the case of batik industry in Malang , East Java-Indonesia. The 4th International Seminar on Sustainable Urban Development. IOP Conf. Series: Earth and Environmental Science, 106: 01206. https://doi.org/doi :10.1088/17551315/106/1/012069

Suhardi, B., Laksono, P. W., \& Fadhilah, N. N. (2017). Analysis of Cleaner Production Implementation in Printed Batik at Batik Puspa Kencana SME In Laweyan Surakarta. Jurnal Teknologi Industri Pertanian, 27(2), 182-191. https://doi.org/10.24961/j.tek.ind.pert.2017.27.2. 182

Susanti, S., \& Manahan, O. (2020). Disease Diagnosis Expert System At Chili Plants Using Bayes Method. Journal Of Computer Networks, Architecture and High Performance Computing, 2(2), 292-296. https://doi.org/10.47709/cnapc.v2i2.432

Syahputra, R., \& Soesanti, I. (2016). Application of Green Energy For Batik Production Process. Journal of Theoretical and Applied Information Technology, 91(2), 249-256.

The Industrial Ministry of Republik Indonesia. (2019). Interested in the global market, batik export is targeted to increase by 8 percent. Retrieved August $10, \quad 2020, \quad$ from https://kemenperin.go.id/artikel/20650/DiminatiPasar-Global,-Ekspor-Batik-Dibidik-Naik-8Persen

Ulya, M., \& Hidayat, K. (2018). Selection of the Best Alternative for Cleaner Production in the Cassava Chips Industry in Support of Sustainable Manufacturing. Rekayasa, 11(2), 110-117. https://doi.org/10.21107/rekayasa.v11i2.4417 
Wardani, M. K., Aulady, M. F. N., Frido, W., \& Hendri, S. (2021). Determining the weight of the hammer based on expert experience for estimating loadcarrying capacity. IOP Conference Series: Materials Science and Engineering, 1010(1). https://doi.org/10.1088/1757899X/1010/1/012041

Yaacob, M. R., \& Zain, N. M. (2016). Modelling Green Batik Industry - A Strategy for Sustainability in the Craft Industry in Malaysia. International Journal of Development and Sustainability, 5(2), 87-97. Retrieved from https://isdsnet.com/ijds-v5n24.pdf 